\title{
Resilience factors in nursing workers in the hospital context*
}

\section{Fatores relacionados à resiliência em trabalhadores de enfermagem no contexto hospitalar Factores relacionados con la resiliencia en trabajadores de enfermería en el marco hospitalario}

How to cite this article:

Silva SM, Baptista PCP, Silva FJ, Almeida MCS, Soares RAQ. Resilience factors in nursing workers in the hospital context. Rev Esc Enferm USP. 2020;54:e03550. DOI: http://dx.doi.org/10.1590/S1980-220X2018041003550

\section{Silmar Maria da Silva ${ }^{1}$ \\ Patricia Campos Pavan Baptista ${ }^{2}$ \\ Fábio José da Silva ${ }^{3}$ \\ Mirian Cristina dos Santos Almeida ${ }^{4}$}

Rosimeire Angela de Queiroz Soares $^{5}$

\footnotetext{
* Extracted from the thesis: "Avaliação e proposta de promoção da resiliência nos trabalhadores de enfermagem de um hospital universitário", Universidade de São Paulo, Escola de Enfermagem, 2017.

${ }^{1}$ Universidade Federal de Minas Gerais, Escola de Enfermagem, Departamento de Enfermagem Básica, Belo Horizonte, MG, Brazil.

${ }^{2}$ Universidade de São Paulo, Escola de Enfermagem, Departamento de Orientação Profissional, São Paulo, SP, Brazil.

${ }^{3}$ Universidade de São Paulo, Hospital

Universitário, São Paulo, SP, Brazil.

${ }^{4}$ Universidade Federal de Tocantins, Palmas, TO, Brazil.

${ }^{5}$ Faculdade de Ciências Médicas da Santa Casa de São Paulo, São Paulo, SP, Brazil.
}

\begin{abstract}
Objective: To investigate the level and factors related to resilience in nursing workers in the hospital context. Method: A cross-sectional study conducted with nursing workers of a university hospital in the city of São Paulo. Data were collected through a questionnaire containing sociodemographic and labor variables and the Resilience Scale. Results: It was found that $45.3 \%$ of the 375 nursing workers investigated had a moderately low/ moderate level of resilience, followed by a moderately high/high level (39.5\%), and then a low level of resilience (15.2\%). Age, working time in the institution, and working time in the profession showed a statistically significant correlation with resilience. The model showed that there is an increase of 0.289 points on the Resilience Scale for each year of age, regardless of the other variables. Conclusion: The resilience level of nursing workers is moderate to high. Age was determinant in resilience, as well as working time in the profession and institution.
\end{abstract}

\section{DESCRIPTORS}

Nursing; Nursing Staff, Hospital; Resilience, Psychological; Occupational Stress; Occupational Health. 


\section{INTRODUCTION}

The category of work in its concrete sense implies the transformation of nature and dialectically imputes its transformation to mankind. This transformation occurs to the extent that there is interaction by man with the object of work, and this depends on their physical and mental apparatus for this transformation.

Concerning nursing workers, studies show that work can greatly influence the health-disease process, not only promoting wear, but also health. The workloads that make up the daily lives of these workers translate into an intensified work rhythm, daily living with the suffering of patients and families, and inadequate human, physical and material resources. Such burdens have given nursing work the attributes of a major stressor, being responsible for accidents, illness and death ${ }^{(1-2)}$.

Stress is an inevitable component of the living process, and is a crucial survival mechanism; however, there is wear and tear due to chronic stress, with brain changes which cause mental health problems ${ }^{(3)}$.

The processes of exhaustion resulting from psychic loads are present in the daily work of nursing workers, compromising their quality of life at work. A study involving 15 nursing workers identified the presence of psychophysical changes such as fatigue, headaches, insomnia, body aches, palpitations, intestinal changes, nausea, tremors, cold extremities, cardiovascular diseases and constant colds, as well as psychological, mental and emotional changes such as decreased concentration and memory, indecision, confusion, loss of sense of humor, anxiety, nervousness, anger, frustration, worry, fear, irritability and impatience ${ }^{(4)}$.

In fact, it is from the experience of adverse situations such as stress that resilience manifests itself, defined as a positive psychosocial adaptation to life events ${ }^{(5)}$. However, responding to adversity with resilience does not mean returning to the original situation after the problem ${ }^{(6)}$, because resilience does not connote the idea of returning to the starting point, but of evolution ${ }^{(7)}$.

The fact is that resilience does not protect the individual from adversity, suffering, stress, make them invulnerable (one of the precursors of the concept), or unattainable, but makes them able to cope, to overcome, to transform and to learn ${ }^{(8)}$.

Nursing worker health imbalance has implications for both worker and institution by increasing absenteeism and presenteeism, compromising the provided care. This can be of value to organizations, to protect and promote workers' mental health while maintaining the quality of work offered ${ }^{(9)}$.

Thus, the question raised is: what is the resilience level of nursing workers inserted in the hospital environment? What factors may be involved in the resilience of these workers? To answer these questions, this study aims to investigate the level and factors related to resilience in nursing workers in the hospital context.

\section{METHOD}

\section{Study Design}

This is a cross-sectional study implementing a quantitative approach.

\section{Population}

The study recruited 375 nursing workers from a university hospital located in the city of São Paulo, which aims at teaching, research and comprehensive multidisciplinary care of medium complexity. At the time of the study, there were 178 beds distributed among the following specializations: medical, surgical, obstetrics and gynecology, pediatrics and orthopedics.

\section{SELECTION CRITERIA}

Inclusion criteria for study participants were: working at the institution for at least six months and providing direct patient care. Therefore, the study did not include workers employed in the administrative areas, in the sterilization and material center, or in the materials management service in the healthcare units.

\section{Data collection}

The level and factors associated with resilience were assessed using the Resilience Scale (RS), an instrument originally developed by Wagnild and Young in 1993, consisting of 25 positively described items distributed between two factors: "Personal competence" and "Acceptance of oneself and life", which have the following as constructs of resilience: serenity, perseverance, self-confidence, sense of life and self-reliance ${ }^{(5)}$.

The RS was translated and validated in Portuguese ${ }^{(10)}$ in 2005, maintaining the 25 items and the same scoring form; however, the items were grouped into three factors which describe the attributes which help in coping with life's problems, such as competence in social relations, problem-solving ability, achieving autonomy, and the meaning or purpose for life and the future: Factor 1 - Resolution of actions and values; Factor 2 - Independence and determination; and Factor 3 - Self-confidence and ability to adapt to situations. For each item, one can either agree or disagree on a scale of 1 (strongly disagree) to 7 (strongly agree), with possible final scores of 25 to 175 points, with a score greater than 145 indicating moderately high to high resilience; a score between 125 and 145 indicative of moderately low to a moderate level of resilience; a score below 125 indicative of low resilience ${ }^{(5,11)}$.

When Cronbach's alpha coefficient was verified for each RS factor, factor 1 presented a value above 0.7 , and factors 2 and 3 presented values below 0.7 ; however, the analysis of the set of questions that compose the RS obtained a Cronbach's alpha coefficient of 0.89 , indicating a satisfactory level of reliability.

A sociodemographic and labor questionnaire was applied on gender, age, marital status, education, working time in the institution, working time in the profession, function, work sector and work shift.

\section{DATA ANALYSIS AND PROCESSING}

Data were entered in a Microsoft Excel $^{\circledR}$ spreadsheet by double independent typing. After verifying data consistency, data analysis was conducted using the Statistical Package for 
Social Sciences $\left(\mathrm{SPSS}^{\circledast}\right.$ ) version 17.0 program. A descriptive analysis was performed using means, standard deviations, medians, minimum and maximum scores of quantitative variables and proportions for qualitative variables.

A univariate analysis was performed in identifying the factors associated with resilience. The Spearman correlation coefficient was used to analyze correlations between quantitative variables and RS score, while the ANOVA test was used to compare the means of the RS according to the categories of qualitative variables with constant variance. The MannWhitney (dichotomous variables) and Kruskal-Wallis (qualitative variables with 3 or more categories) tests were used for variables without constant variance. Tukey's post hoc test was performed for multiple comparisons when a statistically significant difference was found between the means. The homogeneity of the variances was evaluated by the Levene test.

Multiple linear regression analysis was conducted with all variables showing $\mathrm{p}<0.20$ in the univariate analysis. The value of " $p$ " in this analysis determined the entry order into the multiple model. The modeling process was stepwise forward. The independent variable remained in the multiple model if $\mathrm{p}<0.05 \mathrm{and} /$ or if it was an adjustment variable. The qualitative variables were transformed into indicator variables (Dummy), taking the category with the highest mean non-RS score as reference.

Associations were considered significant when $\mathrm{p}<0.05$ in all analyzes.

\section{ETHICAL ASPECTS}

This study was approved by the Research Ethics Committee of the Universidade de São Paulo School of Nursing under Opinion no. 912.483/2014, in accordance with Resolution no. 466/2012 of the National Health Council, which deals with research with human beings. The participants signed the Informed Consent Form after reading and receiving clarifications about the research.

\section{RESULTS}

The study population was predominantly female (87.2\%), with a spouse (married or living with a partner $-60.8 \%$ ) and with higher education (63.7\%). Most (54.5\%) were older than 40.0 years, and $24.6 \%$ were 50.0 years or older. The average age was 41.5 years ( $\mathrm{SD}=9.2$ years), ranging from 23.0 to 65.0 years, with a median of 41.0 years.

The largest proportion of workers were nursing technicians (53.6\%), followed by nurses (37.1\%) and a minority of nursing assistants (9.3\%), all of whom were distributed in similar proportions in all three work shifts (morning, afternoon and night).

Workers had on average 14.0 years (sd $=8.6$ years) working time in the institution, ranging from 1.0 to 34.0 years, with a median of 14.0 years, and $36.8 \%$ had over 18 years. The average working time in the nursing profession was 16.2 years ( $\mathrm{sd}=8.0$ years), ranging from 1.0 to 40.0 years, with a median of 15.0 years, and $36.3 \%$ of workers reported more than 19 years in the profession.

Regarding the work sector, they were allocated into 13 different units: joint accommodation, outpatient, nursery, operating room, obstetric center, surgical clinic, medical clinic, imaging and endoscopy, pediatrics, adult emergency room, child emergency room, adult intensive care unit and pediatric intensive care unit.

The mean RS score was 138.7 points ( $(\mathrm{d}=18.3)$, ranging from 36.0 to 174.0 points and a median of 142.0 points (Table 1).

Table 1 - Descriptive statistics of quantitative variables related to factors and overall resilience score of nursing workers - São Paulo, SP, Brazil, 2015.

\begin{tabular}{|c|c|c|c|c|c|c|}
\hline Factor/score * & $\mathbf{n}$ & Mean & Median & $\begin{array}{l}\text { Standard } \\
\text { deviation }\end{array}$ & Minimum & Maximum \\
\hline 1 - Resolution of actions and values & 375 & 5.5 & 6.0 & 0.8 & 1.0 & 7.0 \\
\hline 2 - Independence and determination & 375 & 5.8 & 6.0 & 0.9 & 1.0 & 7.0 \\
\hline 3 - Self-confidence and ability to adapt to situations & 375 & 5.4 & 5.5 & 0.8 & 2.0 & 7.0 \\
\hline Overall Resilience Score & 375 & 138.7 & 142.0 & 18.3 & 36.0 & 174.0 \\
\hline
\end{tabular}

* Reduced mean score factors ranging from 1 to 7 points. Overall score ranging from 25 to 175 points.

Regarding the factors that make up resilience, it is observed (Table 1 ) that factor 2 had the highest mean (5.8 points; sd = 0.9 points), followed by factor 1 (average 5.5 points; $\mathrm{sd}=0.8$ points), similar to factor 3 (average 5.4 points; sd $=0.8$ points).

When the resilience score is transformed into levels, a moderately low/moderate level (45.3\%) is observed, followed by a moderately high/high level (39.5\%), and $15.2 \%$ presented a low resilience level (Figure 1).

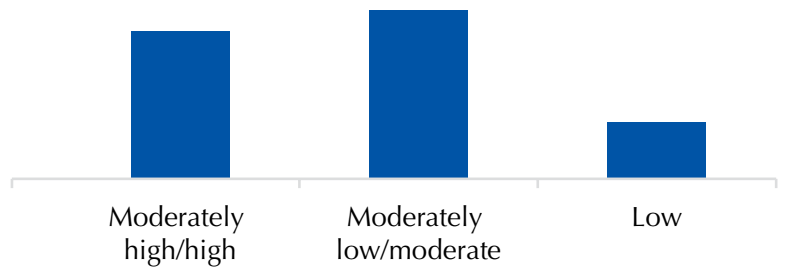

Figure 1 - Distribution (\%) of nursing workers by level of resilience - São Paulo, SP, Brazil, 2015.
There was only a statistically significant correlation with age, working time in the institution and working time in the profession in the analysis of associations of sociodemographic and labor variables with the RS score (Table 2).

Table 2 - Analysis of correlations between quantitative variables and overall resilience score of nursing workers - São Paulo, SP, Brazil. 2015.

\begin{tabular}{lccc}
\hline Variable & $\mathbf{n}$ & $\mathbf{r}^{\left({ }^{()}\right.}$ & $\mathbf{p}$ \\
\hline Age (in years) & 375 & 0.149 & 0.004 \\
Time working in the institution (years) & 375 & 0.131 & 0.011 \\
Time working in the profession (years) & 375 & 0.144 & 0.005 \\
\hline
\end{tabular}

$(\mathrm{S})=$ Spearman correlation coefficient

There was a statistically significant correlation between age and resilience, and the higher the age, the higher the RS score ( $p=0.004 ; r=-0.149)$. Similarly, the higher the RS score, the longer the working time in the institution ( $p$ 
$=0.011 ; \mathrm{r}=-0.131)$, and the longer the working time in the profession ( $p=0.005 ; \mathrm{r}=-0.144)$.

On the other hand, there were no statistically significant differences between the resilience score means and the other variables: gender $(p=0.874)$, marital status $(p=0.750)$, education $(\mathrm{p}=0.109)$, function $(\mathrm{p}=0.209)$, work sector $(\mathrm{p}$ $=0.802)$ and work shift $(\mathrm{p}=0.749)$.

It was possible to explain the resilience behavior in the final results of the multiple linear regression analysis (Table 3).

Table 3 - Factors associated with RS score identified through linear regression analysis of nursing workers - São Paulo, SP, Brazil, 2015.

\begin{tabular}{|c|c|c|c|c|c|c|c|c|}
\hline \multirow{2}{*}{ Variables } & \multicolumn{4}{|c|}{ Univariate } & \multicolumn{4}{|c|}{ Multiple } \\
\hline & $\beta$ & $\mathrm{Cl}_{95 \%}(\boldsymbol{\beta})$ & $\mathbf{p}$ & $\mathbf{r}^{2} \mathbf{a}$ & $\boldsymbol{\beta}$ & $\mathrm{Cl}_{95 \%}(\boldsymbol{\beta})$ & $\mathbf{p}$ & $\mathbf{r}^{2} \mathbf{a}$ \\
\hline Age (years) & 0.289 & {$[0.088 ; 0.490]$} & 0.005 & 0.02 & 0.289 & {$[0.088 ; 0.490]$} & 0.005 & 0.02 \\
\hline Time working in the profession (years) & 0.281 & {$[0.051 ; 0.511]$} & 0.017 & 0.01 & -- & -- & -- & \\
\hline Time working in the institution (years) & 0.265 & {$[0.051 ; 0.479]$} & 0.016 & 0.01 & -- & -- & -- & \\
\hline Education & -3.153 & {$[-7.013 ; 0.707]$} & 0.109 & 0.00 & -- & -- & -- & \\
\hline
\end{tabular}

The final model is represented as follows: $\mathrm{Y}=\mathbf{1 2 6 . 7 2 7}$ $\mathbf{+ 0 . 2 8 9}$ (age); meaning that there is an increase of 0.289 points in the RS for each year of age, regardless of the other model variables.

Thus, the model presented an adjusted coefficient of determination $\left(\mathrm{r}^{2} \mathrm{a}\right)$ of 0.02 , showing that $2.0 \%$ of the total variability of the resilience score can be explained by age, which remained in the multiple modeling.

\section{DISCUSSION}

The results of the present study show that $84.8 \%$ of nursing workers had medium to high levels of resilience, which suggests that participants are already using protective factors, even unknowingly, in coping with adverse work conditions.

The protective factors are those responsible for reducing or eliminating the negative influences arising from risk, i.e. they are internal mechanisms or are learned from the environment in which they live in. Protective factors aim to minimize the effects and deleterious consequences of adversity (chronic stress), as well as restore balance in relation to adversity and facilitate the process of perceiving and facing it ${ }^{(12)}$.

On the other hand, one should consider the phenomenon called the "healthy worker effect". This is the process in which the workers who tend to be healthier remain in the institutions, which is pointed to as a factor of confusion and bias. Although it is difficult to measure, such a factor must be taken into account when interpreting the results ${ }^{(13)}$.

In a study which also used the RS, the score of 56 nursing workers ranged from 86 to 163 points $(\mathrm{SD}=13.79)$. However, the authors chose to perform stratification at their own levels and considered a score between 86 and 110 as low, between 111 and 136 as a medium level, and between 137 and 163 as a high level of resilience. Thus, they found that $50 \%$ of participants had a high level and $42.9 \%$ had a medium level of resilience ${ }^{(14)}$.

High resilience levels are associated with the low prevalence of anxiety symptoms and burnout syndrome. A high resilience level may be considered protective for emotional exhaustion $^{(15-16)}$.

In this sense, resilience plays a preventive role in reducing the negative effects of work-related stress, as well as a promoter in improving workers' mental health ${ }^{(16)}$.
Although an adequate level of resilience among nursing workers is observed in the study, it should be considered that resilience is not a "permanent" but a "temporary" condition. In addition, it has to be committed to promoting health actions.

Thus, a person is not resilient, but a person performs resilient conduct or behavior, because the adverse situations are not static; they change and require changes in resilient behavior as conditions change. Therefore, resilient behavior requires preparation, living and learning from adverse experiences ${ }^{(7)}$.

In promoting healthy work environments for quality of life at work and safe work, it is necessary to strive to maintain workers at a high resilience level stratum, and to encourage moderate workers to try to raise it; for those with low levels, in addition to aiming to reach the next stratum, attention should be paid to detecting and appropriately treating mental distress, which may be expressed by anxiety, burnout or work-related musculoskeletal disorders, as these also contain an emotional component in its genesis.

Regarding the factors which compose resilience, the average in factor 1 (Resolution of actions and values) was 5.5 points (sd $=0.8$ points). This factor maps the behavior of nursing workers in relation to adversities in the workplace. The weaknesses identified in this factor which need attention were the way workers cope with work demands and how they let themselves be affected, as well as the meaning and importance given to what is being done, or even the value of the work itself.

The lack of involvement with work and the lack of interest in work processes may be motivated by the less affective involvement with the patient, by not recognizing the impact of their work on the evolution of patients, or even by not realizing the social value of their work. Thus, workers who perceive to make a difference in their patients' lives may have a more invigorated, dedicated and absorbed feeling in their work, which contributes to their well-being and positive and healthy adaptation ${ }^{(17)}$.

A more positive view of oneself developed through training aimed at improving self-confidence and self-efficacy, as well as social support, could contribute to greater worker involvement in work processes and reducing worry and suffering arising from work dynamics ${ }^{(18)}$.

In addition, in recognizing that resilience predicts workers' personal development, institutional initiatives 
should be implemented with a view to valuing worker potential and autonomy for creative and innovative work by promoting protective factors ${ }^{(19)}$.

In factor 2 - Independence and determination, the average was 5.8 points ( $\mathrm{sd}=0.9$ points). The most fragile item relates to the ability of the nursing worker to feel good about themselves, even if there are people who do not like them.

Workers with low resilience may experience interpersonal conflict at work due to their reduced ability to manage conflict. However, as their resilience level increases, the paralyzing effects of interpersonal conflict at work and the negative situations at work are reduced ${ }^{(20)}$.

The ability to maintain relationships, communicate and live with each other is an imperative factor for nursing work. A healthy relationship, acceptance and recognition from their peers, other workers in the health organization, as well as patients and patients' families are essential for their professional activity and act as a driving force for the worker to work harder and harder to develop their work ${ }^{(21)}$.

The average in factor 3 (Self-confidence and ability to adapt to situations) was 5.4 points (sd $=0.8$ points). The fragile items of this factor relate to the ability to handle situations, as well as not insisting on those where nothing can be done.

The promotion of self-confidence and optimism is essential for workers to feel that they are able to more effectively cope with the demands of their work environment, seeking creative solutions to solve problems, alleviating the effects of stress ${ }^{(20)}$.

Regarding factors associated with resilience, there was a statistically significant correlation between age and resilience, and the higher the age, the higher the RS score. Similarly, the higher the RS score, the longer the working time in the institution and the longer the working time in the profession. Thus, by linear regression, it can be inferred that there is an increase of 0.289 points in RS for each year of age.

No statistically significant relationship was found between resilience and time in the profession when mapping resilience in American nurses ${ }^{(22)}$. However, when investigating stress-generating factors in 134 intensive care unit and coronary unit nursing workers, a Brazilian study evidenced that early-career professionals perform activities under higher demands compared to the others ${ }^{(23)}$.

More time in the profession, clinical experience, knowledge of inside information about people and workplace processes are contributing factors for nurses' positive and healthy adaptation, making them able to cope with the adversities of the workplace, and perceiving oneself as being able to cope ${ }^{(24)}$.

South Korean nurses with longer working hours perceived resilient behavior in daily life such as positive thinking, flexibility, and taking responsibility, which facilitated the shift from negative experiences to positive experiences, from rigidity to flexibility, task-centered thinking to person-centered thinking. In addition, they realized that their resilient behavior was reflected in the team ${ }^{(25)}$.
Years of professional experience are a factor associated with resilience, as resilience is a capacity that develops over time in personal and environmental interactions. In this sense, nursing workers who remain in the profession, despite adverse working conditions, are survivors, committed to change their own reality, while having the opportunity for personal growth and lifelong learning ${ }^{(26)}$.

However, chronic exposure to intense stress in the workplace, regardless of sociodemographic and occupational variables, affects workers' physical and mental well-being and may result in burnout. It is therefore imperative to take a precautionary approach, such as promoting worker resilience as a means of reducing the negative outcomes of stress ${ }^{(27)}$.

When seeking to identify the profile of nursing workers followed by the multiprofessional mental health team of a university hospital, it was found that although they were younger than the other monitored workers, the nursing workers stayed away from work longer, in greater frequency, and had more mental health problems such as affective and mood disorders (54 cases $-58.0 \%$ ) and behavioral syndromes with physiological disorders (21 cases $-22.6 \%)$ from a total of 93 nursing professionals ${ }^{(28)}$.

In response to an intervention to promote resilience, the nursing worker may use protective mechanisms to reduce the harmful effects of work such as their support network (partner, family and friends), support among colleagues in the workplace, positive communication in the workplace, knowledge sharing, experience sharing on patient care and coping with workplace challenges, autonomy, optimism, sense of belonging to the group and to nursing, belief in oneself and the ability to change situations, self-care, self-awareness and self-motivation ${ }^{(24)}$.

Thus, worker welfare is one of the organizational outcomes that should be valued as much as performance ${ }^{(29)}$.

Although the workers evaluated in this study obtained moderate to high resilience scores, its promotion should be an organizational tool aimed at better coping with conditions and adversities at work, as it is understood as a temporary state and not a permanent construct.

\section{CONCLUSION}

The present study aimed to investigate the level and factors related to resilience in nursing workers in the hospital context, showing a moderately low/moderate level in $45.3 \%$ of workers, followed by a moderately high/high level (39.5\%), while $15.2 \%$ had a low level of resilience.

Age was a determinant in the resilience of nursing workers in the hospital context, as well as working time in the profession and institution. However, in the complexity of the human being and their work and in facing adversities present in the work context, personal and environmental resources must be continuously promoted, because resilience is not a "permanent" but a "temporary" condition. 
RESUMO

Objetivo: Investigar o nível e os fatores relacionados à resiliência em trabalhadores de enfermagem no contexto hospitalar. Método: Estudo transversal, realizado com trabalhadores de enfermagem de um hospital universitário da cidade de São Paulo. Os dados foram coletados por meio de um questionário contendo variáveis sociodemográficas e laborais e da Escala de Resiliência. Resultados: Dos 375 trabalhadores de enfermagem investigados, observou-se que 45,3\% apresentam nível moderadamente baixo/moderado de resiliência, seguido pelo nível moderadamente alto/alto, 39,5\%, e baixo nível de resiliência, apresentado por 15,2\%. A idade, o tempo de trabalho na instituição e o tempo de trabalho na profissão apresentaram correlação estatisticamente significativa com a resiliência. Pelo modelo, evidenciou-se que, para cada ano de idade, ocorre aumento de 0,289 pontos na Escala de Resiliência, independentemente das demais variáveis. Conclusão: $\mathrm{O}$ nível de resiliência dos trabalhadores de enfermagem se apresenta moderado a elevado. A idade mostrou-se determinante na resiliência, assim como o tempo de trabalho na profissão e na instituição.

\section{DESCRITORES}

Enfermagem; Recursos Humanos de Enfermagem no Hospital; Resiliência Psicológica; Estresse Ocupacional; Saúde do Trabalhador.

\section{RESUMEN}

Objetivo: Investigar el nivel y los factores relacionados con la resiliencia en trabajadores de enfermería en el marco hospitalario. Método: Estudio transversal, realizado con trabajadores de enfermería de un hospital universitario de la ciudad de São Paulo. Los datos fueron recogidos mediante un cuestionario conteniendo variables sociodemográficas y laborales y la Escala de Resiliencia. Resultados: De los 375 trabajadores de enfermería investigados, se observó que el 45,3\% presentan nivel moderadamente bajo/moderado de resiliencia, seguido del nivel moderadamente alto/alto, el 39,5\%, y bajo nivel de resiliencia, presentado por el 15,2\%. La edad, el tiempo de trabajo en el centro y el tiempo de trabajo en la profesión presentaron correlación estadísticamente significativa con la resiliencia. Por el modelo, se evidenció que, para cada año de edad, ocurre incremento de 0,289 puntos en la Escala de Resiliencia, independientemente de las demás variables. Conclusión: El nivel de resiliencia de los trabajadores de enfermería se presenta moderado a elevado. La edad se mostró determinante en la resiliencia, así como el tiempo de trabajo en la profesión y el centro.

\section{DESCRIPTORES}

Enfermería; Personal de Enfermería en Hospital; Resiliencia Psicológica; Estrés Laboral; Salud Laboral.

\section{REFERENCES}

1. Abreu RMD, Gonçalves RMDA, Simões ALA. Motivos atribuídos por profissionais de uma Unidade de Terapia Intensiva para ausência ao trabalho Rev Bras Enferm [Internet]. 2014 [citado 2016 dez. 18];45(5):1083-8. Disponível em: http://www.scielo.br/scielo.php?script=sci_ arttext\&pid=S0034-71672014000300386\&lng=pt\&nrm=iso\&tlng=pt

2. Urbanetto JS, Magalhaes MCC, Maciel VO, SantAnna VM, Gustavo AS, Poli-de-Figueiredo CE, et al. Work-related stress according to the demand-control model and minor psychic disorders in nursing workers. Rev Esc Enferm USP [Internet]. 2013 [cited 2016 Dec 18];47(5):1180-6. Available from: http://www.scielo.br/scielo.php?script=sci_arttext\&pid=S0080-62342013000501180\&lng=en\&tlng=en

3. King A. Neurobiology: rise of resilience. Nature (Lond.). 2016;531(7592):S18-19. DOI: https://doi.org/10.1038/531S18a

4. Ramos EL, Souza NVDO, Gonçalves FGA, Pires AS, Santos DM. Quality of work life: repercussions for the health of nursing worker in intensive care. Rev Pesqui Cuid Fundam. (Online) [Internet]. 2014 [cited 2016 Dec 18];6(2):571-83. Available from: http://www.seer.unirio. br/index.php/cuidadofundamental/article/view/2833

5. Wagnild GM, Young HM. Development and psychometric evaluation of the Resilience Scale. J Nurs Meas. 1993;1(2):165-78.

6. Wagnild, GM. The Resilience Scale User's Guide for the US English version of the Resilience Scale and the 14-Item Resilience Scale (RS14) [Internet]. New York: The Resilience Center; 2009 [cited 2016 Dec 18]. Available from: http://www.resiliencecenter.com/resilienceproducts/publications-including-the-true-resilience-book/resilience-scale-users-guide/

7. Grotberg EH. Introdução: novas tendências em resiliência. In: Melillo A, Ojeda ENS, organizadores. Resiliência: descobrindo as próprias fortalezas. Porto Alegre: Artmed; 2005. p. 15-22.

8. Brandao JM, Mahfoud M, Gianordoli-Nascimento IF. The construction of the concept of resilience in psychology: discussing the origins of resilience. Paidéia (Ribeirão Preto) [Internet]. 2011 [citado 2016 dez. 18];21(49):263-71. Disponível em: http://www.scielo.br/scielo. php?script=sci_arttext\&pid=S0103-863X2011000200014\&lng=pt\&tlng=pt

9. Noben C, Evers S, Nieuwenhuijsen K, Ketelaar S, Gärtner F, Sluiter J et al. Protecting and promoting mental health of nurses in the hospital setting: is it cost-effective from an employer's perspective? Int J Occup Med Environ Health. 2015;28(5):891-900. DOI: http://dx.doi. org/10.13075/ijomeh.1896.00465

10. Pesce RP, Assis SG, Avanci JQ, Santos NC, Malaquias JV, Carvalhaes R. Adaptação transcultural, confiabilidade e validade da escala de resiliência. Cad Saúde Pública [Internet]. 2005 [citado 2016 dez. 18];21(2):436-48. Disponível em: http://www.scielo.br/scielo. php?script=sci_arttext\&pid=S0102-311X2005000200010\&lng=pt\&tlng=pt

11. Wagnild GM. A review of the resilience scale. J Nurs Meas. 2009;17(2):105-113. DOI: http://dx.doi.org/10.1891/1061-3749.17.2.105

12. Pesce RP, Assis SG, Santos N, Oliveira RVC. Risco e proteção: em busca de um equilíbrio promotor de resiliência. Psicol Teor Pesqui [Internet]. 2004 [citado 2016 dez. 18];20(2):135-43. Disponível em: http://www.scielo.br/scielo.php?script=sci_arttext\&pid=S0102$37722004000200006 \& \operatorname{lng}=p t \& t \operatorname{lng}=p t$

13. Shah D. Healthy worker effect phenomenon. Indian J Occup Environ Med. 2009;13:77-9. DOI: http://dx.doi.org/10.4103/0019-5278.55123

14. Rocha FLR, Gaioli CCLO, Camelo SHH, Mininel VA, Vegro TC. Organizational culture of a psychiatric hospital and resilience of nursing workers. Rev Bras Enferm [Internet]. 2016 [cited 2017 Jan 11];69(5):765-7. Available from: http://www.scielo.br/pdf/reben/v69n5/en_00347167-reben-69-05-0817.pdf

15. Silva SM, Borges E, Abreu M, Queirós C, Baptista P, Felli V. Relationship between resilience and burnout: mental and occupational health promotion among nurses. Rev Port Enferm Saúde Mental [Internet]. 2016 [cited 2017 Jan 11];16:41-8. Available from: http://www.scielo. mec.pt/pdf/rpesm/n16/n16a06.pdf 
16. Arrogante O. Mediator effect of resilience between burnout and health in nursing staff. Enferm Clin. 2014;24(5):283-9. DOI: https://doi. org/10.1016/j.enfcli.2014.06.003

17. Santos A, Chambel MJ, Castanheira F. Relational job characteristics and nurses' affective organizational commitment: the mediating role of work engagement. J Adv Nurs. 2016;72(2):294-305. DOI: https://doi.org/10.1111/jan.12834

18. Gottardo LFS, Ferreira MC. Suporte social, avaliações autorreferentes e bem-estar de profissionais de saúde. Arq Bras Psicol [Internet]. 2015 [citado 2016 dez. 18];67(1):146-60. Disponível em: http://pepsic.bvsalud.org/pdf/arbp/v67n1/11.pdf

19. Monteiro AC, Mourão L. Resiliência e justiça organizacional como antecedentes da percepção de desenvolvimento profissional. Psicol Teor Pesqui [Internet]. 2016 [citado 2017 jan. 11];32(1):111-21. Disponível em: http://www.scielo.br/scielo.php?script=sci_ arttext\&pid=S0102-37722016000100111\&lng=pt\&tlng=pt

20. Martinez-Corts I, Demerouti E, Bakker AB, Boz M. Spillover of interpersonal conflicts from work into nonwork: a daily diary study. J Occup Health Psychol. 2015;20(3),326-37. DOI: http://dx.doi.org/10.1037/a0038661

21. Thofehrn MB, Montesinos MJL, Jacondino MB, Fernandes HN, Gallo CMC, Figueira AB. Processo de trabalho dos enfermeiros na produção de saúde em um hospital universitário de Múrcia Espanha. Ciênc Cuid Saúde [Internet]. 2015 [citado 2016 dez. 18];14(1):924-32. Disponível em: http://periodicos.uem.br/ojs/index.php/CiencCuidSaude/article/view/22094/14352

22. Rushton $\mathrm{CH}$, Batcheller J, Schroeder K, Donohue P. Resilience among nurses practicing in high-intensity settings. Am J Crit Care. 2015;24(5):412-21. DOI: http://dx.doi.org/10.4037/ajcc2015291

23. Silva JLL, Teixeira LR, Soares RS, Costa FS, Aranha JS, Teixeira ER. Estrés y factores psicosociales en el trabajo de enfermeros intensivistas. Enferm Glob [Internet]. 2017 [citado 2011 nov. 21];16(48):80-120. Disponible en: http://scielo.isciii.es/scielo.php?script=sci_ arttext\&pid=S1695-61412017000400080\&lng=es

24. McDonald G, Jackson D, Vickers MH, Wilkes L. Surviving workplace adversity: a qualitative study of nurses and midwives and their strategies to increase personal resilience. J Nurs Manag. 2016;24(1)123-31. DOI: http://dx.doi.org/10.1111/jonm.12293

25. Kim M, Windsor C. Resilience and work-life balance in first-line nurse manager. Asian Nurs. Res. 2015;9(1):21-7. DOI: http://dx.doi. org/10.1016/j.anr.2014.09.003

26. Cope V, Jones B, Hendricks J. Resilience as resistance to the new managerialism: portraits that reframe nursing through quotes from the field. J Nurs Manag. 2016;24(1):115-22. DOI: http://dx.doi.org/10.1111/jonm.12279

27. McCann C, Beddoe E, McCormick K, Huggard P, Kedge S, Adamson C et al. Resilience in the health professions: a review of recent literature. Int J Wellb. 2013;3(1):60-81. DOI: http://dx.doi.org/10.5502/ijw.v3i1.4

28. Araújo GS, Sampaio AS, Santos EM, Barreto SMG, Almeida NJV, Santos MLD. Perfil de trabalhadores de enfermagem acompanhados por equipe multiprofissional de saúde mental. Rev Rene [Internet]. 2014 [citado 2016 dez. 18]:15(2):257-63. Disponível em: http://www. periodicos.ufc.br/rene/article/view/3134/2408

29. Puente-Palacios KE, Pacheco EA, Severino AF. Clima organizacional e estresse nas equipes de trabalho. Rev Psicol Organ Trab [Internet]. 2013 [citado 2016 dez. 18];13(1):37-48. Disponível em: http://pepsic.bvsalud.org/scielo.php?script=sci_arttext\&pid $=$ S1984-66572013000100004 